\title{
Mini-Review: Covid and Vitamin D
}

\author{
Carbajal Ana and Giner Merce* \\ Department of Normal and Pathological Cytology and Histology, University of Seville, Avda Dr. Fedriani s / n 41009 Seville, Spain
}

Submission: April 06, 2021; Published: July 15, 2021

*Corresponding author: Giner Merce, Department of Normal and Pathological Cytology and Histology, University of Seville, Avda Dr. Fedriani s / n 41009 Seville, Spain

Keywords: Covid-19; SARS CoV2; Vitamin D; Mortality; Comorbidity

\section{Mini Review}

Since the end of 2019, COVID19 has spread throughout the world, affecting millions of people, and causing many deaths, mainly the elderly [1]. In the last year, numerous studies have been developed whose main objective is to know the mechanisms of action of the COVID-19 disease. In this sense, the possible role of Vitamin D is highlighted as a molecule with the potential to mitigate infection through its interaction with the immune system, specifically through the activation or repression of several genes in the promoter region of which it binds to the element of response to vitamin D. Currently, it is still complex to understand the mechanisms used by vitamin $\mathrm{D}$ in relation to the modulation of the immune system and the application of this aspect in the protection against infection caused by COVID-19. There are different points of view regarding the role that vitamin D plays in COVID-19 disease, in the same way that there are several studies in which a positive relationship is found between adequate levels of vitamin D and longer survival to the disease [2,3], others refer to a higher risk of mortality in a group of patients taking vitamin D supplements [4-6].

On the other hand, there are studies that show a favourable relationship between vitamin D levels and less aggressiveness of the COVID-19 [7-12]. Daneshkhah et al. [8] He related, through a meta-analysis of a series of studies, the fact of having appropriate levels of vitamin D with a lower risk of developing an overactivation of the immune system that led to what we know as a cytokine storm, finding an apparently significant relationship However, there are a series of limitations in this study, such as the lack of vitamin D status and cytokine levels in COVID-19 patients before and after infection, that is, there was not enough information to affirm that the use of vitamin D is therapeutic.
In line with the studies that support the benefit of vitamin D in patients with COVID-19, those whose design has been experimental or quasi-experimental should be highlighted, providing a more solid level of evidence in this regard. One of these studies is the one carried out by Training et. al, in this study to avoid the difference in the distribution of pathologies such as hypertension or diabetes, a multivariate logistic regression analysis was carried out, as a conclusion it was found that the administration of a high dose of calcifediol or 25-hydroxyvitamin D3, significantly reduced the need for ICU treatment for patients requiring hospitalization for COVID-19. Despite having used techniques to obtain comparable patient samples, other limitations were found in this study, such as the fact that a placebo control group was not used, which demonstrated the superiority of vitamin D over it [13].

In that of Annweiler et al. [14] to demonstrate the prognostic benefits of vitamin D bolus supplementation both in the year prior to the diagnosis of COVID-19 and after, a control group was not used with which to compare the effects of vitamin $D$, in addition there is a risk of having made a $\beta$ type error due to the small size of each of the groups analysed, which reduces the power of the study $[14,15]$.

In view of the different data provided, one should speak cautiously regarding the relationship between vitamin D and COVID-19, since although most studies find benefits in vitamin D supplementation of patients with COVID-19, it could be incurring an overestimation of this effect by ignoring important elements such as risk factors or the presence of inadequate sample sizes, so it would be necessary to carry out more studies to correct these elements. Before reaching a definitive conclusion regarding these 
studies, a more detailed analysis of the different factors that may be involved in the development of more serious forms of COVID-19 disease such as hypertension, diabetes, ischemic heart disease.

\section{References}

1. Wu F, Zhao S, Yu B, Chen YM, Wang W, et al. (2020) A new coronavirus associated with human respiratory disease in China. Nature 579(7798): 265-269.

2. Hossein-Nezhad A, Holick MF (2013) Vitamin D for health: A global perspective. Mayo Clin Proc 88(7): 720-755.

3. Aparna P, Muthathal S, Nongkynrih B, Gupta SK (2018) Vitamin D deficiency in India. J Fam Med Prim care 7(2): 324-330.

4. Pereira M, Dantas Damascena A, Galvao Azevedo LM, de Almeida Oliveira T, da Mota Santana J (2020) Vitamin D deficiency aggravates COVID-19: systematic review and meta-analysis. Crit Rev Food Sci Nutr 4: 1-9.

5. Mercola J, Grant WB, Wagner CL (2020) Evidence regarding vitamin d and risk of covid-19 and its severity. Nutrients 12(11): 1-24.

6. Cereda E, Bogliolo L, Lobascio F, Barichella M, Zecchinelli AL, et al. (2021) Vitamin D supplementation and outcomes in coronavirus disease 2019 (COVID-19) patients from the outbreak area of Lombardy, Italy. Nutrition 82: 111055 .

7. Carpagnano GE, Di Lecce V, Quaranta VN, Zito A, Buonamico E, et al. (2020) Vitamin D deficiency as a redictor of poor prognosis in patients with acute respiratory failure due to COVID-19. J Endocrinol Invest 44(4): 765-771.
8. Daneshkhah A, Agrawal V, Eshein A, Subramanian H, Roy HK, et al. (2020) Evidence for possible association of vitamin D status with cytokine storm and unregulated inflammation in COVID-19 patients. Aging Clin Exp Res 32(10): 2141-2158.

9. Radujkovic A, Hippchen T, Tiwari-Heckler S, Dreher S, Boxberger M, et al. (2020) Vitamin D deficiency and outcome of COVID-19 patients. Nutrients 12(9): 1-13.

10. Dancer RCA, Parekh D, Lax S, D'Souza V, Zheng S, et al. (2015) Vitamin D deficiency contributes directly to the acute respiratory distress syndrome (ARDS). Thorax 70(7): 617-624.

11. Park S, Lee MG, Hong SB, Lim CM, Koh Y, et al. (2019) Effect of vitamin D deficiency in Korean patients with acute respiratory distress syndrome. Korean J Intern Med 34(3): 685.

12. Grant WB, Lahore H, McDonnell SL, Baggerly CA, French CB, et al. (2020) Evidence that vitamin d supplementation could reduce risk of influenza and covid-19 infections and deaths. Nutrients 12(4): 1-19.

13. Entrenas M, Manuel L, Costa E, Bouillon R, Francisco J (2020) Effect of calcifediol treatment and best available therapy versus best available therapy on intensive care unit admission and mortality among patients hospitalized for COVID-19: A pilot randomized clinical study. J Steroid Biochem Mol Biol 203: 105751.

14. Annweiler C, Hanotte B, Grandin de l'Eprevier C, Sabatier JM, Lafaie L, et al. (2020) Vitamin D and survival in COVID-19 patients: A quasiexperimental study. J Steroid Biochem Mol Biol 204: 105771.

15. Annweiler G, Corvaisier M, Gautier J, Dubee V, Legrand E, et al. (2020) Vitamin d supplementation associated to better survival in hospitalized frail elderly covid-19 patients: The geria-covid quasi-experimental study. Nutrients 12(11): 1-12.

\section{Your next submission with Juniper Publishers} will reach you the below assets

- Quality Editorial service

- Swift Peer Review

- Reprints availability

- E-prints Service

- Manuscript Podcast for convenient understanding

- Global attainment for your research

- Manuscript accessibility in different formats ( Pdf, E-pub, Full Text, Audio)

- Unceasing customer service

Track the below URL for one-step submission https://juniperpublishers.com/online-submission.php 